


\section{Devotional Negotiation with the Archducal Government}

Over the course of August 1616, some four years after the miracles had resumed, the Zoutleeuw authorities were approached by a highranked military officer. A delegation of representatives of church and city, consisting of the dean of the collegiate chapter, the burgomaster and a churchwarden, was sent to the nearby town of Sint-Truiden for a meeting with an unidentified commisaris Generael, about 'the holy relic of our patron Saint Leonard.' ${ }^{1}$ This was to be the first in a series of intense and relatively costly negotiations to obtain a relic of Saint Leonard for the collegiate church, the meetings for which took place primarily in Brussels during the first weeks of November. The parish priest, the burgomaster and a messenger, each in turn, went to the court city to follow up on the developments in the case. ${ }^{2}$ These meetings proved to be fruitful: on 14 November a deed of gift was drawn up before a Brussels notary. The document declared that Don Luis de Velasco, general of the light cavalry of the Spanish army in the Low Countries and presumably the man referred to as commisaris Generael, donated part of Saint Leonard's cranium to the Zoutleeuw church, as he was convinced that it would be venerated there with due reverence. With this in mind, he handed over the relic to Abbot Godfried Lemmens (r. 16o9-1627) of Vlierbeek Abbey, one of the two patrons of the Zoutleeuw church. ${ }^{3}$ As the Tridentine decrees had specified that 'no relics [were to be] recognized, unless they have been investigated and approved' by the bishop, ecclesiastical control had become more strict in this regard. ${ }^{4}$ Therefore, the abbot presented a request to authenticate the relic to Archbishop Mathias Hovius, who in turn declared the relic to be authentic on 28 November, ironically ignoring the fact that Saint Leonard's complete skull was said to be kept in Saint-Léonard-de-Noblat. ${ }^{5}$ After these necessary formalities, preparations for the solemn ceremony of translation could be made in Zoutleeuw. The relic finally entered the town on 11 December $1616 .{ }^{6}$ It is still preserved in the church, in a seventeenth-century silvered wooden reliquary bust (fig. 144). ${ }^{7}$
Figure 15 , detail Frans Hogenberg, Joyous Entry of Archduke Albert in Brussels, c. 1596-1598, Amsterdam, Rijksmuseum

(C) RUBEN SUYKERBUYK, 2020 | DOI:10.1163/9789004433106_011

This is an open access chapter distributed under the terms of the CC BY-NC-ND 4.o license. 


\section{FIGURE 144}

Anonymous, Reliquary bust of Saint Leonard, Zoutleeuw, church of Saint Leonard PHOTO: AUTHOR

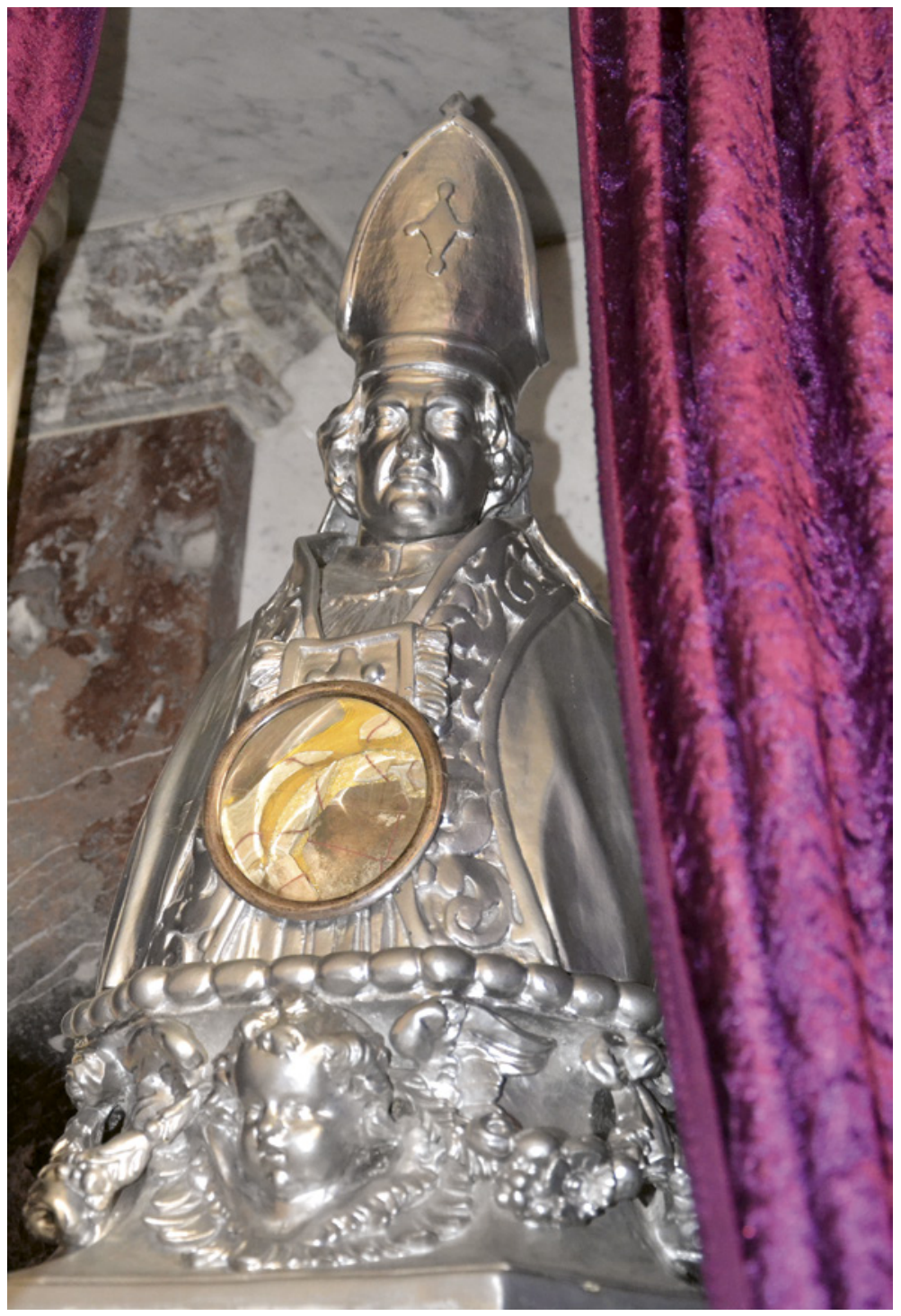

\section{The Object of Devotion: Image versus Relic}

This late donation of a relic to an already established shrine of Saint Leonard is striking, and it added a new theological layer to the local cult and its object of devotion. The available evidence indeed suggests that prior to 1616 no relic of the saint was venerated in Zoutleeuw. Liturgically, of course, every consecrated altar needed to contain a relic in or under its base (stipes), but these did not necessarily have to be of the titular saint. Moreover, being carefully 
wrapped up and placed in a securely closed cavity, these particular sacred remains were never visible. ${ }^{8}$ As a result, contrary to miraculous statues or relics acquired after the altar consecration, they could not be viewed, let alone be touched by the worshippers, nor could they be carried around in sanctifying communal processions. Invisible relics in altars were therefore not explicitly presented as part of a church's sacred treasury, and did not serve as cultic focal points. ${ }^{9}$ The only cult object documented in Zoutleeuw, prior to the 1616 donation, is Saint Leonard's statue (fig. 18). Jan Caussarts, the man from Kuringen who had reportedly taunted the Zoutleeuw cult and its pilgrims in 1555 , clearly attacked a wooden sculpture, not a relic, and sixteenth-century accounts merely mention the statue of Saint Leonard as being carried around in the Whit Monday procession. It is only in the earliest preserved account dating from after the translation that a relic is added to the ceremony. ${ }^{10}$ Other subsequent sources, including a 1625 inventory and a town chronicle dating to the 165 os, consistently speak of the relic, singular. ${ }^{11}$ Thus, up until 1616, the Zoutleeuw cult of Saint Leonard only centered around a miraculous statue rather than the saint's bodily remains.

In this respect, it is a typical late medieval cult. From a panEuropean perspective, the cult of relics chronologically preceded the cult of images, enjoying an absolute peak in popularity between the eight and twelfth centuries. It was only because relics had already been introduced that sculptures were eventually allowed into churches. The acceptance of relics made it more difficult to raise claims of idolatry against statues. ${ }^{12}$ Only in the thirteenth and fourteenth centuries did the popularity of relics dwindle in favor of images. Reliquaries were increasingly given figural, human forms, fusing the cult of relics into the cult of images. The latter were gradually being treated as relics and even assumed their roles as far as supernatural powers were concerned. Images - either painted or sculpted - grew ever more costly and became potent even without containing the actual bodily remains of the saints they represented. ${ }^{13}$ Eventually this led to a theology of localization whereby places became pilgrimage sites because of the particular image of the saint the shrine housed. ${ }^{14}$

Nevertheless, relics and images remained two entirely distinct theological entities, and the rise of the image as cult object certainly did not mean that relics were discarded altogether. On the contrary, relics continued to take up a central place in cult centers such as Saint Rumbold in Mechelen or Saint Gumarus in Lier, and a significant amount of Protestant critiques were devoted to speaking out 
against them, demanding the abolition of their cults. Much like attacks on other Catholic practices, theological critiques of relics were based on a long tradition. But in the sixteenth century critiques were both more widespread and more radical, not calling for a mere correction of abuses, but an outright abolition of the practice. While Luther was still relatively tolerant when it came to the cults of saints and images, he could not accept relics in any way. ${ }^{15}$ As a result, they formed a prime target for iconoclasts in general, and for the Geuzen in the Low Countries in particular. During and after the Beeldenstorm many churches were robbed of their relics, which in most cases were immediately destroyed in order to deprive them of their possible powers. ${ }^{16}$ Aartselaar's relic of Saint Leonard, for instance, befell this very fate sometime before $1572 .{ }^{17}$

Protestant hostility greatly contributed to the renewed popularity and traffic of relics in Catholic Europe. In the 157 os and 158 os a largescale relocation took place, safeguarding them from Protestant territories. The opening of the Roman Catacombs in 1578 further fueled this development, as the graves of supposed proto-Christian martyrs were mined as a relic treasure-trove. Moreover, in 1588 the Catholic Church started a new canonization campaign after a 65-year hiatus, creating an increased demand for the remains of these newfound saints. ${ }^{18}$ This increasing mobility of relics was thus part and parcel of the Catholic restoration, as the Church of Rome used them both in order to incorporate its various, local devotions, and to demonstrate the Church's continuity with the pre-Reformation past. ${ }^{19}$ In the Low Countries, relics generally moved from the northern to the southern provinces. In Alem, for instance, the corpse of Saint Odrada was unearthed around 1600 and brought to nearby 's-Hertogenbosch, after which the bishop distributed fragments of the corpse to institutions in Catholic territories. Fleeing Catholic exiles also took their personal religious material culture with them, including relics. ${ }^{20}$

Many relic donations were motivated by theological reasons and had much to do with the old issue of the problematic character and ambiguous nature of sculpture. After all, the Ten Commandments had particularly forbidden 'graven images' (sculptile). Throughout the Middle Ages, three-dimensional sculpture was also considered much more lifelike than paintings, 'for the very reason of its being tactile and physically present', and many theoretical frameworks from the twelfth and thirteenth centuries onwards therefore ascribed negative connotations to the medium. ${ }^{21}$ Unsurprisingly therefore, Protestant critiques mostly focused on sculpted idols. Jan Caussarts had specifically attacked Zoutleeuw's wooden statue of 
Saint Leonard, and Veluanus had demanded that all grove beelden be removed from the temples and burned. They were all too easily treated as idols, he maintained, and even if that was not the case yet, they could only do harm because the danger of idolatry always remained. ${ }^{22}$ During the Beeldenstorm, this unease with threedimensional images was made manifest through focused attacks on the medium of sculpture, which were arguably greater than those on paintings. ${ }^{23}$

In emphasizing the benefits of images, the decrees of the Council of Trent had only referred in very general terms to sacra imago, not specifying any particular medium. In line with local Italian tradition and custom, this mostly refers to the less problematic medium of painting rather than sculpture, however, while the latter on the contrary was by far the predominant medium of miraculous images in the Low Countries. Valérie Herremans has pointed out that subsequent provincial councils and diocesan synods in the Low Countries maintained this emphasis on the art of painting. ${ }^{24}$ All this meant that the sculptures, already subject to attack, had an even more ambiguous theological status, and remained an issue with which the Church did not always feel comfortable. Cults such as the one at Zoutleeuw were especially problematic in this respect, as they were not only centered around a miraculous statue, but were moreover also focused on a saint, who, contrary to the omnipresence of Christ, were only considered to be really present on earth in their bodily remains. ${ }^{25}$ This is why cults such as that in Zoutleeuw qualified well for the sacred approval by adding a relic, which would provide it with a firm theological backbone, and at the same time also revive the early Christian principle of relics as protectors of images against critiques of idolatry. ${ }^{26}$

Such a reading can be substantiated by the example of Johannesschüsseln, sculptures of the decapitated head of Saint John the Baptist on a platter. While medieval examples rarely served as reliquaries in the Low Countries, it has been shown how many of the sculptures began to take on such a function after 1575. A striking example is documented in the church of Saint John the Baptist of Kachtem (Flanders). In his 1642 visitation report, the bishop of Bruges noted the particular local devotion for a sculpted head of the church's patron saint, but he remarked that it did not contain a relic. He therefore ordered the church to acquire one and put it in the sculpture, and temporarily forbade all devotion of the image ${ }^{27}$ In this case, the acquisition was clearly the result of an active move toward Catholic Reformation on the part of the ecclesiastical authorities. 
On the other hand, similar motivations cannot be demonstrated for the case of Zoutleeuw: comparable indications are lacking and the well-preserved yearly visitation reports remain silent about the donation of the relic. Furthermore, it was placed in an independent reliquary rather than in Saint Leonard's statue. It is clear that the relic did not replace the miraculous statue, since both were carried separately during the yearly procession. This testifies to the latter's continued key role during the seventeenth century. ${ }^{28}$ Thus, the motivations for donating the relic were not purely theological, and a better understanding can be reached of what it meant to donate the relic by performing an anthropological reading of political factors.

\section{The Gift}

While ecclesiastical authorities were conspicuously absent in the story of the Zoutleeuw relic, representatives of the archducal court played a major role. In particular the donor of the relic, Don Luis de Velasco (1559-1625) holds a prominent place in the record. The intitulatio of the deed of gift refers to him as 'hault et puissant Sr. messire Don Louys de Velasco, Marquis de Bellebeder [Belveder], chevalier de lordre de Saint Jacques, commandeur de Valentia del Ventoso, capitaine general de la cavallerie legere de larmee de Sa Majesté en ses Pays Bas et de son conseil de guerre'. These titles are illustrative of how high he stood in the Spanish king's favor, and how close he was to the archducal court of Albert and Isabella. Not only was he an important commander-in-chief of the Spanish army in the Low Countries, he was also a member of the regional Council of War, Archduke Albert's advisory organ in matters of warfare. Particularly relevant is the fact that he was deployed by Albert in the Rhineland, at the eastern border of the Low Countries, from 1614 onwards. ${ }^{29}$ Moreover, several of his sons served as page (menino) in the service of Isabella. His high status in Habsburg circles is also reflected in his membership of the Orden Militar de Santiago de la Espada, wherein he served as commander of Valencia del Ventoso (Extremadura). This was a highly prestigious order of knights that was incorporated in the Spanish monarchy, and thus is ample evidence of royal favor. ${ }^{30}$ The correspondence of King Philip III reveals his particular satisfaction with Velasco's military services, and already in 1603 and 1605 he promised him rewards. However, in 1610 Velasco still complained about the meagre recompense he received after thirty years of dutiful service, and only in January 1616 would he be endowed 


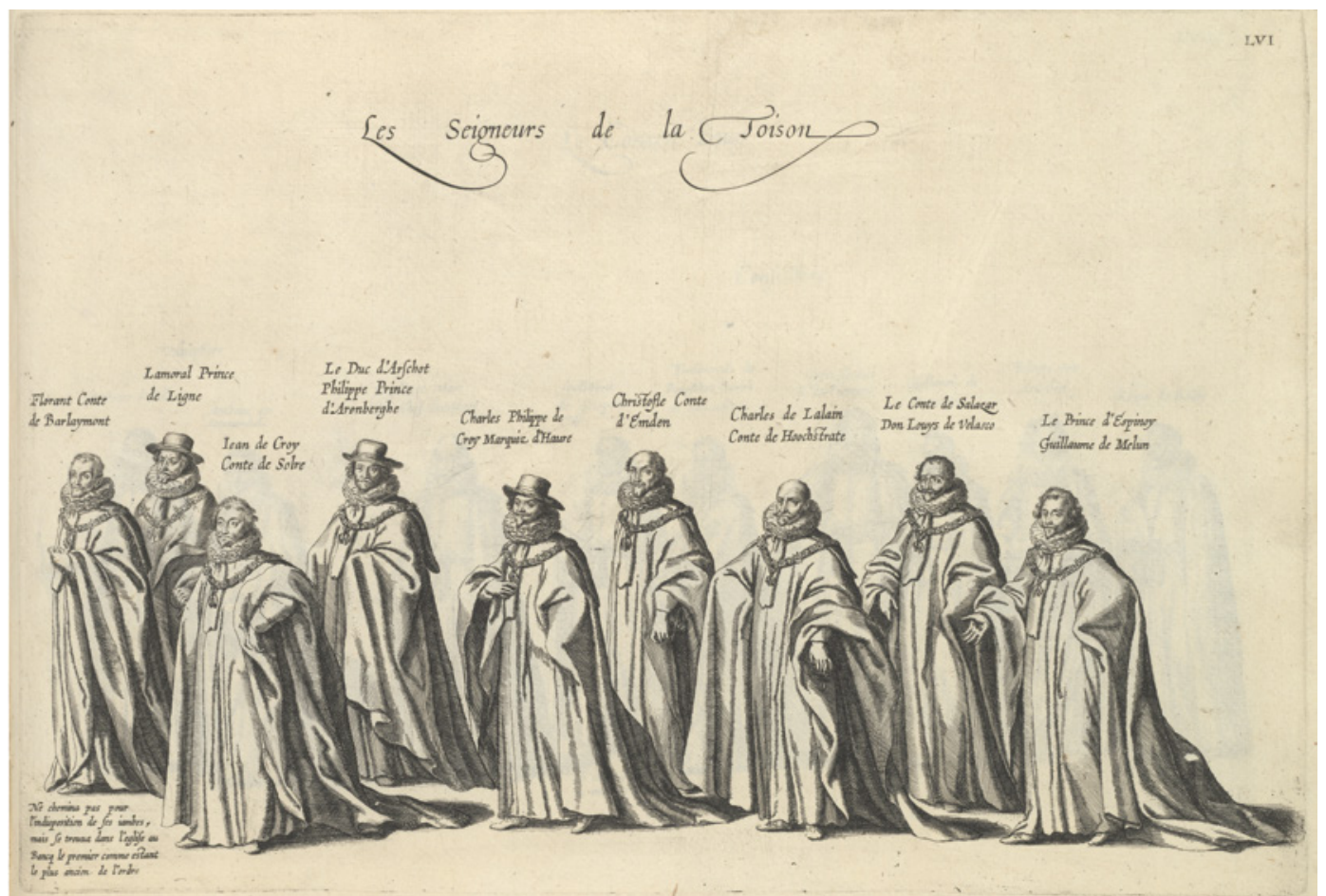

with the title of Marquis of Belveder. ${ }^{31}$ The title of Count of Salazar would follow in 1621. By the time of Albert's death in the same year he was also elected knight in the Order of the Golden Fleece, and, in that role, walked right behind the coffin in the archduke's funeral procession (fig. 145). ${ }^{32}$

It is unclear whether the town of Zoutleeuw actually asked for a relic, but it is clear that it was a gift. This important fact needs to be emphasized. Geary has applied anthropological frameworks to the study of the circulation mechanisms of relics in the Middle Ages, and he has highlighted the consequences of relics being acquired as gifts, rather than through theft or purchase. When gifts were given, no payment in currency was demanded from the receiving party, but there was an alternative 'price' in the unwritten agreement, namely obedience. The act of giving a relic thus created power relationships whereby the donating party underlined its power and importance. Or, to describe the same dynamic using a more peaceful language, a personal relationship of 'brotherly love' was established between donor and receiver. ${ }^{33}$ More studies of relic donations in early modernity would be needed in order to determine the validity of this argument on a general level. Nevertheless, it will be demonstrated that Geary's
FIGURE 145

Cornelis Galle after Jacques

Francquart, The knights of the Order of the Golden Fleece in Archduke Albert's funeral procession, in Puteanus 1623, pl. 56, Ghent, University Library 
observations on the medieval period apply neatly to the Catholic Low Countries in the later sixteenth and early seventeenth centuries.

Under the reign of the archdukes, the traffic of relics became a state affair. ${ }^{34}$ They were arguably the greatest collectors of relics of their era and both assembled an impressive collection. This interest evidently had its roots in their predecessors Charles v and especially Philip II, whose relic collection eventually counted more than 7000 examples from all over his empire, including those 'saved' from the northern Low Countries. They were stored in the royal monastery of San Lorenzo de El Escorial, which thereby became a sort of national depot of sanctity. ${ }^{35}$ The archdukes continued this rescue operation. In 1610, during the calmer years of the Twelve Years' Truce, court historiographer Jean-Baptiste Gramaye proposed Archduke Albert to secure all relics of saints still located in the Dutch Republic and bring them to the Catholic south. ${ }^{36}$ After having travelled around for four years to draw up an inventory and copy the necessary documents, he was given permission in 1614 to commence the operation. ${ }^{37}$ Its most famous episode was the relocation of the body of Saint Lidwina in 1615. Soon after her death in 1433 she had drawn many pilgrims to the chapel built above her grave in Schiedam, but the town's alteration in 1572 put an end to her cult there. It instigated Gramaye to save her remains from Protestant hands, but a first attempt caused consternation, leading to the arrest of the hired gravedigger by the Reformed town council, who accused him of instigation to idolatry. A second attempt was successful, however, and the relics were brought to the archdukes' private oratory in Brussels. Yet, contrary to Philip II, Albert and Isabella would subsequently redistribute them to several other religious institutions in the Low Countries from 1616 onwards. ${ }^{38}$ On the other hand, the court also reacted to local initiatives to recover the artifacts. The example of the Blessed Idesbald, third abbot of the Abbey of the Dunes, illustrates this point. After the sacking of the abbey in 1566 , the Cistercian community fled to Bruges. Around 1600 the monks returned and soon started to look for the remains of their illustrious abbot. In November 1623 a leaden coffin was found in the chapter house, which was officially opened by the Bishop of Ieper in April 1624. The ensuing ceremony was widely attended by abbots and other clergymen from all over Flanders. An intense devotion would quickly follow, and in 1625 Isabella visited the abbey and received a personal relic of Idesbald to mark the occasion. ${ }^{39}$

The archducal court thus became a key player in a web of sacred gift transactions, knitting together the Catholic provinces of the Low Countries. Velasco gave the relic to Zoutleeuw in his own name, but 
personal links with the town hardly seem to have played a role in this case. In part, the deed of gift emphasizes Velasco's personal piety, referring to the 'great devotion, honor and reverence he holds for the blessed Saint Leonard'. However, the text also reveals that Velasco desired that the saint's relics would be placed 'in a holy place, there where they would be shown due reverence', and that he was 'well assured that this would be the case in the collegiate church of Saint Leonard in the town of Zoutleeuw' ${ }^{40}$ However, we cannot establish a single link between Velasco and the town of Zoutleeuw since his name is not mentioned once in the Zoutleeuw sources and he was not attached to the garrison quartered in the city in any direct way, and indeed might not even have been present in the translation ceremony. ${ }^{41}$ But his donation was evidently in keeping with wellestablished and still prevailing practices at the Habsburg court, of which he himself was part. Since the gift coincided with Gramaye's notorious and large-scale relic relocation campaign, the archducal connotations of Velasco's gift must have been equally obvious to contemporaries. But his choice for Zoutleeuw is intriguing and merits closer scrutiny, because the Low Countries counted several other centers of devotion to Saint Leonard (map 4, p. 95).

Although discussed as a gift, it is also crucial to underline the aspect of negotiation that was involved in the transaction. The successive meetings between the two parties in Sint-Truiden and Brussels have been referred to above, but other, simultaneous discussions with the government had taken place well before. Although Zoutleeuw had housed a garrison since $15^{6} 5^{-1566}$ and was of strategic interest due to its location at the border, it had suffered greatly during the war and its infrastructure and economy were in considerable decline. Thus, after the disastrous troubles of the sixteenth century the town council of Zoutleeuw repeatedly asked for financial aid - in the form of, for example, an extension of payment of taxes or economic privileges - for infrastructural restorations and in particular for renewed ramparts. In 1597, for instance, Philip II granted the town the privilege of having a weekly cattle market, and in 1606 and 1612 Zoutleeuw was granted two respective extensions of payment. ${ }^{42}$ But the situation had not changed that much by 1616-1617, however, when similar requests are amply documented. Interestingly, as in the case of the relic, it also involved negotiations with the governmental institutions. These negotiations brought delegates from Zoutleeuw to Brussels for longer periods. Town clerk Jan Bollen, for instance, stayed from 7 until 16 November 1616 in order to obtain a quittance of 700 guilders, and he was sent again from 20 November until 14 December for the same reason as well as 'in order to come 
to the fortification of this town. ${ }^{43}$ The same was still the case in 1617 , when several requests were sent 'to the lords Estates for the obtainment of some measure for the repair of this town' ${ }^{44}$ The state of the ramparts was inspected, after which an estimation of the 'necessary reparations' was drawn up. At the same time complaints were uttered about the oppressive military presence, and attempts were made to obtain a set of regulations for the soldiers as well as a prison. These requests clearly reflect underlying tensions between town and government, and in particular a discontent with the military state of affairs and its consequences on town life. The supplications did not all remain unanswered. In the context of the general restoration of Catholic infrastructure in the Low Countries, between 1615 and 1621 the archdukes made several financial donations to the Zoutleeuw convent of Bethania and the cloister of the Beghards. ${ }^{45}$ But there were of course limits to their aid, since help was needed all over the southern provinces. Eventually, the town would only receive their renewed ramparts in 1642 , followed by the construction of a citadel between 1671 and 1679.46

Connecting the donation of the relic with this particular situation provides further insights, and three interrelated aspects of its symbolic value should be pointed out. In the first place the gift of a relic served as an extra stimulus to the revival of the cult of Saint Leonard, which the town as a whole would benefit from. After all, in the early seventeenth century relics of Saint Leonard were still rare in the Low Countries. At the shrine in Liège, for example, the cult object was also a statue, and when in 1650 a relic was given to the church as votive offering for a received healing, it was not one of its patron saint. ${ }^{47}$ The church of Aartselaar had received a relic in the later fifteenth century, but it was destroyed by $\mathbf{1 5 7 2}$. No origin prior to 1616 could be established for any of the other centers, and in his 1628 catalogue of relics in the Low Countries, Arnold de Raisse only mentions one of Saint Leonard in Râches, near Douai. ${ }^{48}$

An asset for the Zoutleeuw shrine, the relic would contribute to a restoration, not only of the cult, but also of the local social fabric. As patron saints were considered protectors of their hosting communities, it goes without saying that receiving such a saint's bodily remains had a profound impact on the identity of Catholic communities after a traumatic period. William Christian has pointed out for later sixteenth-century Spain that relics 'reinforced community pride and chauvinism' by rehabilitating the shared, communal religion. ${ }^{49}$ Even more so than in late sixteenth-century Spain, the towns and villages in the Low Countries would benefit from such a 
reinforcement during the short period of peace of the Twelve Years' Truce, as they had been torn apart by religious strife - literally and figuratively. Like the archdukes, De Raisse also believed that relics could heal the country of 'its sickness of the soul.'50 The communal role of the Zoutleeuw relic is illustrated by the fact that it was immediately included in the town's yearly procession at Whit Monday in honour of its patron saint, and by its proud description in a town chronicle dating to the 1650 s. $^{51}$

The role of relics in the restoration of a community's pride and identity is directly related to the important political role they could play. This had become painfully clear during the most intense periods of the troubles. Precisely because relics were inherently related to specific communities and, therefore, to particular social and political orders, their destruction was a very conscious attempt to break with a past or regime that was no longer accepted by Protestants. ${ }^{52}$ Conversely, relics that had been spared from destruction during a period of Protestant occupation would later on play a crucial role in the installment of the renewed Catholic order. In Mechelen, for instance, the relics of Saint Rumbold had been scattered as a result of a sacking of the cathedral during the city's Calvinist regime (1580-1585). After the Catholic reconquest, the saint's remains were reunited and solemnly reinstalled in the cathedral's choir in 1586, an event that was accompanied by a ceremonial elevatio at the occasion of which indulgences were issued. This reunification, and therefore the city's unity and return to Catholicism, would be commemorated annually. ${ }^{53}$ Similarly, whenever French Catholics took power in the sixteenth and seventeenth centuries, these events were accompanied by processions with, and exhibitions of, relics. Still in early modern times, control over sacred remains - especially those of a patron saint - was equated with control over the town that hosted them, and the public appropriation of local cults often bore fruit in terms of accumulation of public authority in the eyes of the community. ${ }^{54}$ Conversely, by virtue of their perceived protective power over communities, relics could also serve as substitutes for public power. ${ }^{55}$ In this sense, the donation of the relic of Zoutleeuw's patron saint by a Habsburg officer and member of the archducal court would no doubt reconfirm the bonds between the town and the ruling authority. Regardless of existing tensions, the town was definitively incorporated into their Catholic empire.

A third and final aspect of relics' symbolic values is related to patron saints' roles as protectors and defenders of towns and communities. By carrying the principal cult object in procession through the 
parish, the space was simultaneously consecrated and placed under the protection of the saint. Usually such processions took place once a year, but in times of crisis, such as in cases of war or epidemics, their frequency was often increased.$^{56}$ However, it was generally believed that protection and defense could only be secured by means of their permanent and physical presence through relics. ${ }^{57}$ This has been aptly demonstrated in the case of Cologne and its relics of the Eleven Thousand Virgins. When an attack on the city in 1268 had been successfully warded off, this was attributed to the defense of the city's army of female patron saints. This story was enforced by repeating it time and again in both text and image, and the key role of relics was increasingly emphasized. This was certainly not a uniquely medieval affair, as in 1619 the narrative was brought to the fore once again. ${ }^{58}$ Similarly, Zoutleeuw's patron saint would only be considered permanently present, and therefore able to protect the town and its community of inhabitants, if the relic of Saint Leonard was in place.

The defensive properties of relics were particularly relevant for Zoutleeuw, especially considering the profile of the donor: he was a military officer who invested the garrison town with the protective shield of its patron saint. An interesting example for comparison is provided by the town of Uceda in Spain (Guadalajara). In 1574 its church received a set of relics of the Eleven Thousand Virgins from a certain Juan de Bolea, who had served as an officer under the Duke of Alba in the Low Countries. In the subsequent report the community sent to King Philip II, it was stated that he had saved them from the hands of the heretics, 'as a good captain and defender of the Christian faith. ${ }^{59}$ This example illustrates the important role ascribed to officers in the protection and circulation of relics. Yet, contrary to this previously discussed pattern of relics being saved from Protestant territories to Spain, Saint Leonard's relic instead travelled in the opposite direction. Possibly even coming from Spain itself, it was given by a Spanish general to a town in the Low Countries that had been threatened by Protestant forces during the troubles. ${ }^{60}$ Thus, in the contemporary political context, the protective connotations of the relic were well understood.

Of course, in the first place, the sacred protection concerned the town and jurisdiction of Zoutleeuw itself, but in a broader sense it also related to the whole region of the Catholic Low Countries. After all, as a garrison town at the border of the Duchy of Brabant, Zoutleeuw occupied an important position in the protection of the frontier to the Habsburg territories. From 1568 onwards, the town had been the subject of military strategies from both Catholic and 
Protestant armies, and this continued well into the seventeenth century. Still in 1635 , for instance, a Franco-Dutch alliance entered Brabant via its eastern frontier and immediately occupied Zoutleeuw. ${ }^{61}$ It would therefore not be surprising that an underlying rationale of the gift was the turning of the garrison town into a Catholic stronghold, sacrally strengthening the frontier of the Low Countries. Various countries are known to have put up a 'wall of relics' as defense against Protestants. Jeffrey Chipps Smith described the rationale behind the Dukes of Bavaria's quest for relics in Protestant lands and their subsequent collection in Munich as transforming their capital 'into a mighty fortress of Catholic faith' ${ }^{62}$ Similar motivations are discernable in the archdukes' policy, and their relic collection has been interpreted as apotropaic, a conscious strategy 'of amassing sacral power within their territories' ${ }^{63}$ Scholars have demonstrated that much the same principles were at play in Scherpenheuvel, which was a clear manifestation of archducal Catholic militancy. ${ }^{64}$ This is evident, first of all, in the fortified town's ground plan which is shaped in the form of the religiously charged heptagon. ${ }^{65}$ Furthermore, the shrine was located on territory that used to be property of the princes of Orange. Finally, the town lay on the front line, and the fact that the archdukes chose a place close to the territories controlled by the Protestant army was certainly no coincidence. That particular detail was indeed also emphasized by contemporary authors, such as Philips Numan, who explained that the shrine's many miracles might work as a factor that might convince the nearby Protestants of the truth of the Catholic Church. ${ }^{66}$ As the devotion to Our Lady was still highly controversial, the pilgrims to the shrine would moreover be turned into militant Catholics, instead of mere opportunistic believers.

Why Velasco chose Zoutleeuw rather than, say, Sint-Lenaarts, which was also home to a cult of Saint Leonard and practically lay on the front line itself, remains an object of speculation. But the fact that Sint-Lenaarts was only a small village, and that Zoutleeuw was garrison town could have played a role in the decision. In that capacity it was doubtless much more relevant to a military leader. Furthermore, the cult of Saint Leonard in Zoutleeuw had only recently experienced a new impulse with a fresh series of miracles starting in 1612. It can be presumed that this devotional revival had attracted the attention of the archducal court, including Velasco, who must have realized the town's relative importance. After all, Zoutleeuw was located close to 'their' shrine of Scherpenheuvel, a place which Velasco had also visited as pilgrim himself in the company of fellow Spanish officers in the summer of 1607.67 The successions of events 
in both places thus show striking parallels, with members of the Habsburg court responding to the increasing popularity of a local pre-existing cult. Like Zoutleeuw, Scherpenheuvel had seen a steady rise in miracles in the years immediately preceding the archducal interventions (Chapter 8). Already on 8 September 16o3 - i.e. well before the Archdukes' lavish patronage began, and even before the episcopal approval - an immense crowd of reportedly 20,0oo pilgrims had come to visit the shrine. ${ }^{68}$ Thus, there is no direct causal relationship between Habsburg interventions and the devotional revival. On the contrary, Albert and Isabella clearly responded to preexisting processes and local initiatives. ${ }^{69}$ The revival of Catholicism preceded governmental actions, but these added significant layers of meaning. While Velasco did not provide Zoutleeuw with the requested fortifications, he nevertheless provided the town with the sacred protection of its patron saint, thus reviving a medieval principle. Through the gift of the relic, the bonds with the archducal government were reinforced, turning the garrison town at the border into a militant, orthodox stronghold and strengthening the frontier of their Catholic territories.

\section{The Translation}

Bringing the putative fragment of Saint Leonard's cranium to Zoutleeuw generated new values and significance. Strictly speaking, relics had no material value. Instead, the value they had was attributed to them by the hosting community, and was therefore to a large extent localized. Furthermore, the value and meaning that sacred remains had accumulated in one community was not automatically transposed when they were transferred to another. A new cultural transformation was needed in order for the relic to once again acquire status. This happened in translatio ceremonies: 'formal, liturgical processions in which remains of saints were officially recognized and transported from one place to another. ${ }^{70}$ These were usually very costly public rituals, which involved detailed organization undertaken by special committees. Not only were such events attended by the most important regional religious and political elites, but they also attracted large crowds. ${ }^{71}$ The practice already existed in the early Middle Ages, but in the later sixteenth and early seventeenth centuries translatio ceremonies were particularly encouraged and became widespread. ${ }^{72}$

In Zoutleeuw, the fabrica ecclesiae and the civic authorities shared the costs and the responsibility for organizing the events. 
Celebrations started with a copious breakfast for the highest guests and their servants. Among those present were of course members of the local religious and civic elite, including the town council, the aldermen and town governor, Thomas de Wijngaerde. Furthermore, the presence of at least three high-ranked, mitered abbots of the most important nearby abbeys is documented: Godfried Lemmens, Abbot of Vlierbeek, Jean de Frayteur, Abbot of Heylissem (r. 16121645), and Jean Druys (r. 16o1-1634), Abbot of Parc Abbey. ${ }^{73}$ The churchwardens served the guests a wide variety of dishes, including chicken, beef, goose, duck, pork and veal, and fish 'since it was Advent for the prelates'. This all was combined with bread, cheese, butter, fruit, oats, almonds, sugar and spices. ${ }^{74}$ The ceremony itself mainly consisted of a procession, in which the relic was carried from the refugium of the Abbey of Heylissem, at the western edge of town next to Saint John's chapel, to Saint Leonard's church (fig. 3). This route from the ramparts to center was specially cleaned for the purpose, and the church received extra decorations. ${ }^{75}$ Headed by four standard-bearers and under the sound of chiming bells, the relic was carried in procession through the city streets with 'great solemnity'. The parade brought it to the middle of the church, where it was displayed in a tabernacle and illuminated by burning torches. ${ }^{76}$ Even before the liturgical celebrations in the church began, the event was celebrated with the necessary ceremonial pomp and circumstance. Upon entering the city's marketplace, the parade passed through a temporary wooden arch, decorated with coats of arms by painter Jacop Lambrechts. The square itself was illuminated by a big lantern, suspended on a line that was hung between the church building and the town hall, emphasizing their shared roles. The accounts also mention the presence of decorative elements such as tabernacles, probably installed throughout town along the road that the procession followed. Finally, reference is made to a specktakel - presumably a play depicting Saint Leonard's life, organized by the city's chamber of rhetoric. ${ }^{77}$

While the urban ceremonies of Joyous Entries have been well studied, relic translations in the Low Countries have received less scholarly attention. This is surprising because - as is also the case with the entries of sovereigns - an analysis of how such rituals were locally designed and customized reveals the crucial issues at stake. ${ }^{78}$ It is difficult to establish whether or not the 1616 Zoutleeuw ceremony followed an established, pre-Reformation tradition. But a documented example of Saint Eustachius' church in Zichem, dating to 1517 , only mentions that a relic of its patron saint was 'enthroned with honorable hymns and chants', in the company of the parish priest 


\section{FIGURE 146}

Goswijn van der Weyden,

Translation of Saint

Dymphna, 1505, Antwerp,

Phoebus Foundation

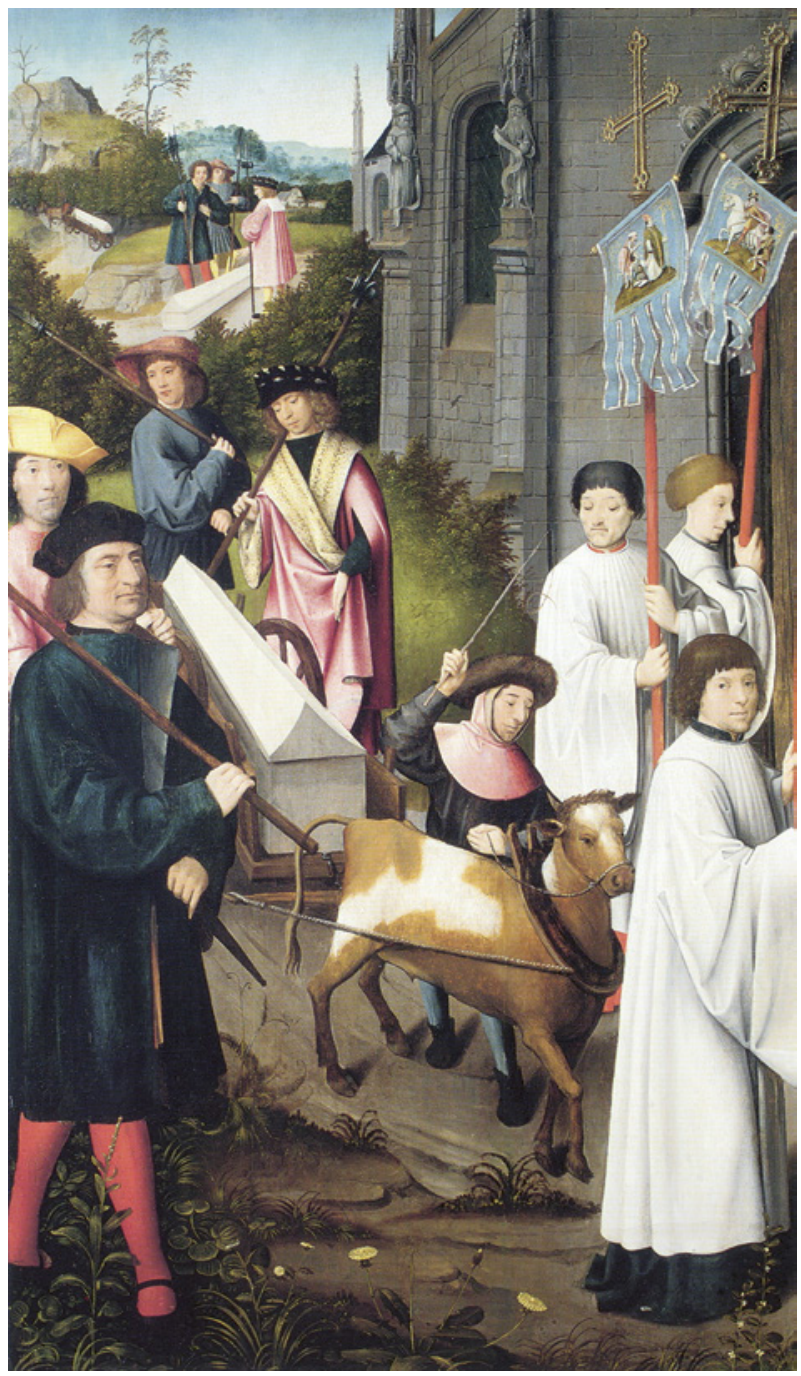

and the local lord (villicus). No reference is made to related civic ceremonies that might have taken place outside of the church. ${ }^{79}$ Some rare iconographic examples, such as Goswijn van der Weyden's 1505 depiction of the translation of Saint Dymphna (fig. 146), help to visualize the processions, and emphasize the role of the clergy, but do not suggest elaborate pomp. One of the few points of immediate resemblance is the presence of two clerical standard-bearers leading the procession. These similarly figure in the translation of Saint Stephen as represented by Jan vander Coutheren in $15^{22}$, which also documents the presence of bishops or mitered abbots (fig. 147). 


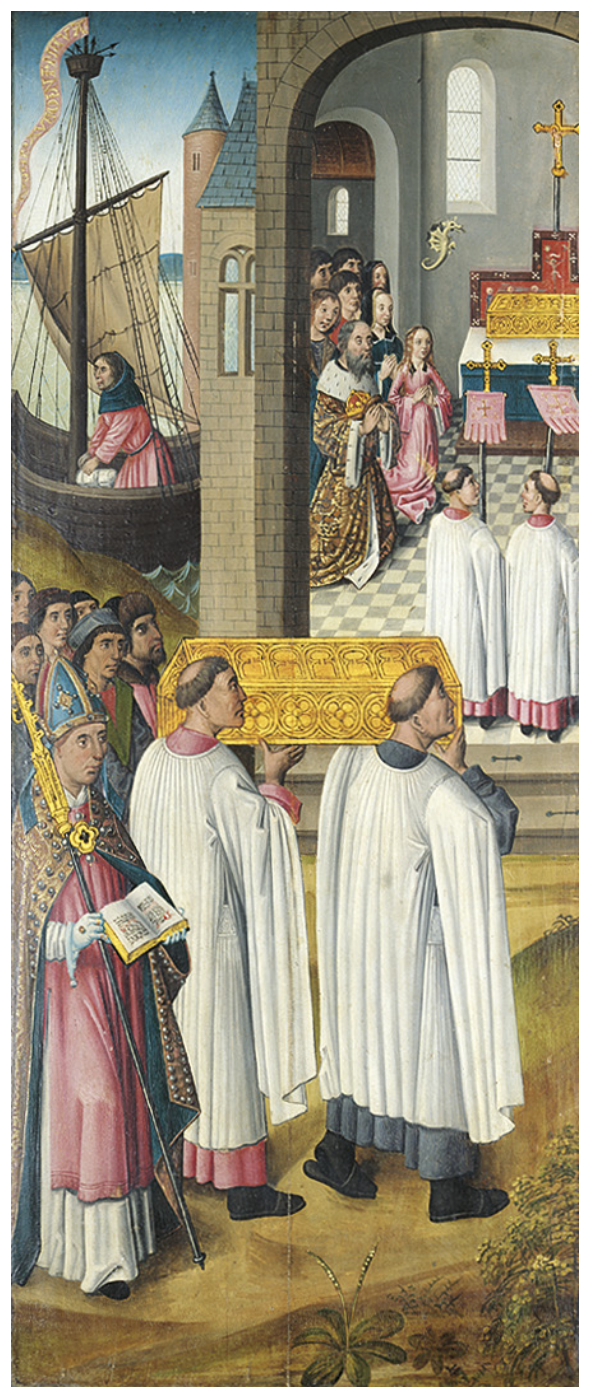

FIGURE 147

Jan vander

Coutheren,

Translation of

Saint Stephen, 1522,

right inner wing

of the altarpiece

of Saint Stephen,

Korbeek-Dijle,

church of Saint

Bartholomew

PHOTO: JOHAN

GELEYNS - RO SCAN

However, a comparison of the 1612 Zoutleeuw festivities with other early seventeenth-century examples from the southern Low Countries reveals much more pomp and greater civic involvement at work. One of the best documented contemporary examples in the Low Countries is the translation into Lille on 22 January 1612 of a certain Saint Victor - unrelated to his better-known namesakes venerated in Marseille and Xanten - 'and his companion'. They were two of the many corpses dug up from the Roman catacombs, identified as early Christian martyrs and sent all over the Christian world as newly discovered relics. ${ }^{80}$ Saint Victor and his companion were 
donated to the Lille city council by Claudio Acquaviva, Superior General of the Jesuits, in gratitude for its support of the order. The construction of their new church, completed in 1611, had indeed been financed with civic money. The translation ceremony and the surrounding festivities have been amply described in a contemporary town chronicle and in an official account by local Jesuit Jean Buzelin, which was printed in 1612 and paid for, at least in part, by the magistracy. A delegation of the Lille political elite met the convoy with the saints' bodies just outside the ramparts and accompanied them to the city gate, where they were welcomed by the town council and the local clergy. After having spent the night in a chapel just outside the city walls, the relics' actual translation ceremony started the next day. They were carried in a solemn procession with abbots and the Bishop of Tournai, intermediately making stops and posing the bodies at five altars along the way. The sumptuous parade passed through several temporary triumphal arches, and during the day multiple cannon volleys were to be heard, and bonfires and theatrical spectacles to be seen. The very first miracles reportedly happened on the day of the translation itself. ${ }^{81}$

The Jesuits played a crucial role in the Lille ceremony. The order was central in the redistribution of relics, and as such they had an important influence on the precise form of the processions and festivities. The Jesuits were of course known for their sumptuous celebrations, stimulating the onlookers' sensory experiences in many ways. But similar celebrations, involving multimedia campaigns also occurred in translation ceremonies where the order was not involved. ${ }^{82}$ A well-known example from the same year as the Lille ceremony is the translation of Saint Albert of Leuven from Reims to Brussels. The event was initiated by Archduke Albert for dynastical reasons, as this saint was a member of the ducal house of Brabant, and he had put substantial pressure on the Archbishop of Reims to hand over his patron saint's body to him. Eventually the translation took place on 13 December 1612. The body was carried through the city streets by four mitered abbots, while it was carried into the church of the Discalced Carmelites by Archduke Albert himself, together with general Ambrogio Spinola, Philip William, Prince of Orange, and the Spanish envoy. Inside, the authentication ritual followed. Just as in Lille, an official report of the ceremony was published by court confessor Andrés de Soto, both in Spanish and French. ${ }^{83}$ Elaborate media campaigns would frequently recur in later translation ceremonies. 
The saints that were thus carried around were carefully selected. It is obvious why Archduke Albert desired to have the body of his name saint close to his court in Brussels, and his spouse actually did the same with her own patron, Saint Elizabeth. ${ }^{84}$ Another example of a state-sponsored ceremony with a clear underlying ideological motivation was the translation of the Martyrs of Gorkum to the Brussels Franciscan convent in October 1618. This group of nineteen clerics had been hanged in 1572 by the Geuzen in Den Briel, because they were protecting a consecrated host from profanation. Although their beatification would only take place in the later seventeenth century, they soon became the most famous Catholic martyrs of Protestant violence in the Low Countries. Thus, the choice of having their remains transferred to Brussels was not only a symbolic and open condemnation of Protestant atrocities, but also a conscious statement on the Eucharist. The procession that was organized at the occasion of the translation reportedly counted more than 5000 participants, and as was the case in the examples mentioned above, a booklet including a description of the events was printed immediately afterwards. ${ }^{85}$

The Zoutleeuw ceremonial thus tied in with a broader contemporary European pattern. Visual sources on these ceremonials are scarce, but a print depicting a 1698 translation in Augsburg depicts an important, oft-recurring element (figs. 148 \& 149). Before entering the cathedral, the parade passed through a triumphal gate, an element that was equally present in Zoutleeuw and Lille, among many other places. ${ }^{86}$ While in medieval translations relics were sometimes treated and even addressed as lords, the ceremonies were now often explicitly modelled after antique, Roman triumphal marches. ${ }^{87}$ Richard Krautheimer and, more recently, Minou Schraven have both convincingly demonstrated how this was part of a broader papal project that had started under Paul III (r. 1534-1549) wherein the city of Rome was being reinvented in a new, Christian form. It legitimized the ancient city as the capital of Christianity and, consequently, underlined the primacy of the Roman Catholic Church. Post-Tridentine rhetorical language made deliberate use of triumphal imagery to establish an image of Christian victory over the older triumphs of pagan Antiquity. ${ }^{88}$ From 1575 onwards, such ideals were put into practice during relic translation ceremonies by Charles Borromeo in Milan and Gabriele Paleotti in Bologna in particular. As was typical for the general paleochristian revival, these churchmen 


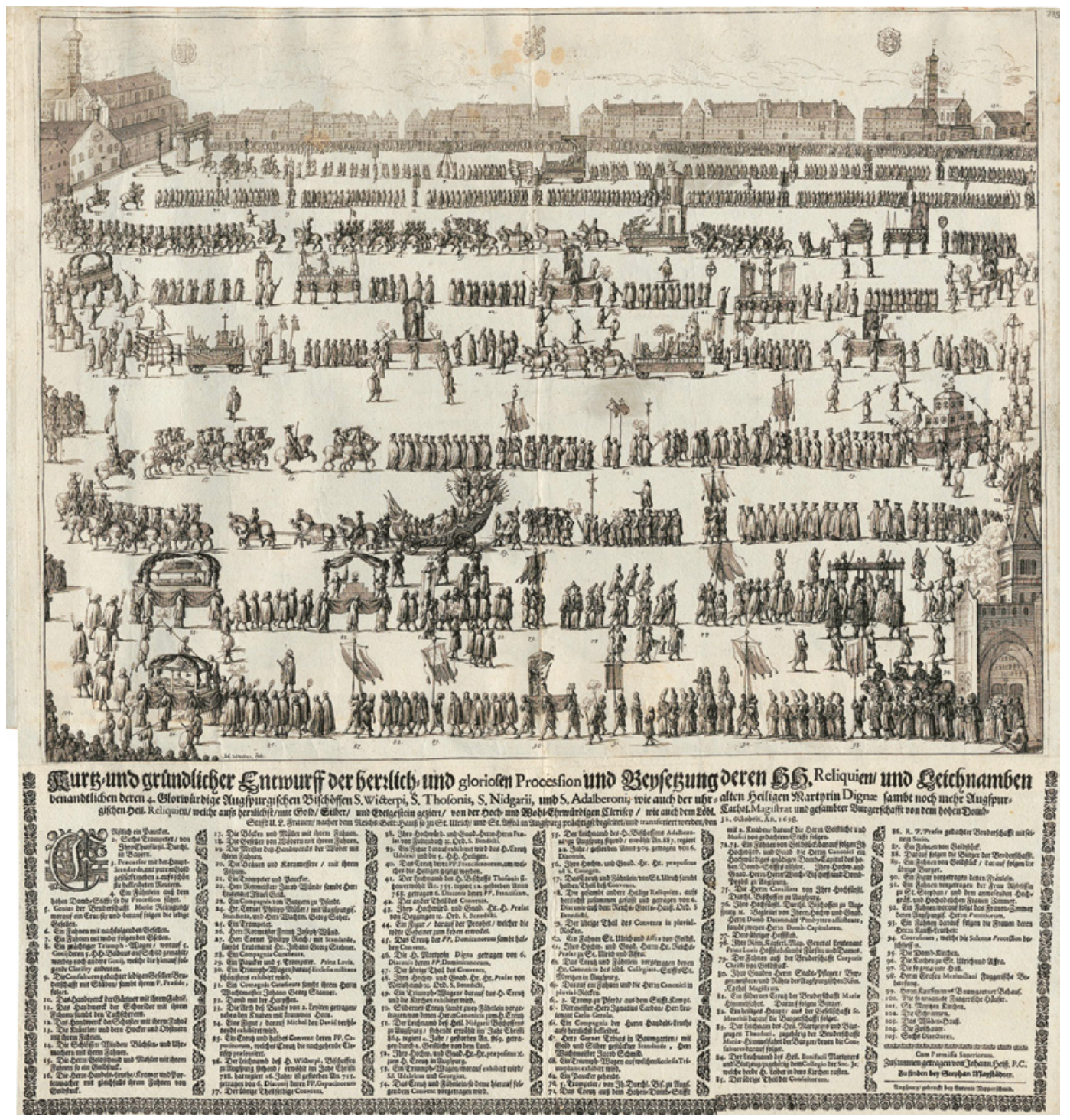

FIGURE 148

Johann Weidner (after),

Translation of four Augsburg bishops and other relics to the church of Saints Ulrich and Afra, 1698, Arolsen, Fürstlich Waldeckschen Hofbibliothek based themselves on the church fathers, especially Saint Ambrose, who had described relics as trophies. Martyrs in particular had long been associated with military victory in hagiographical texts, which would eventually lead to them being viewed as Christian soldiers. ${ }^{89}$ Sacred remains thus lent themselves perfectly to Christian triumphal marches. In Milan and Bologna temporary arches were constructed, but when the practice spread to Rome the processions would also pass through the actual antique structures on the Forum Romanum. As such, these ceremonies were powerful visualizations of the triumph of a 'militant cult of church history and saints' ${ }^{90}$ By 


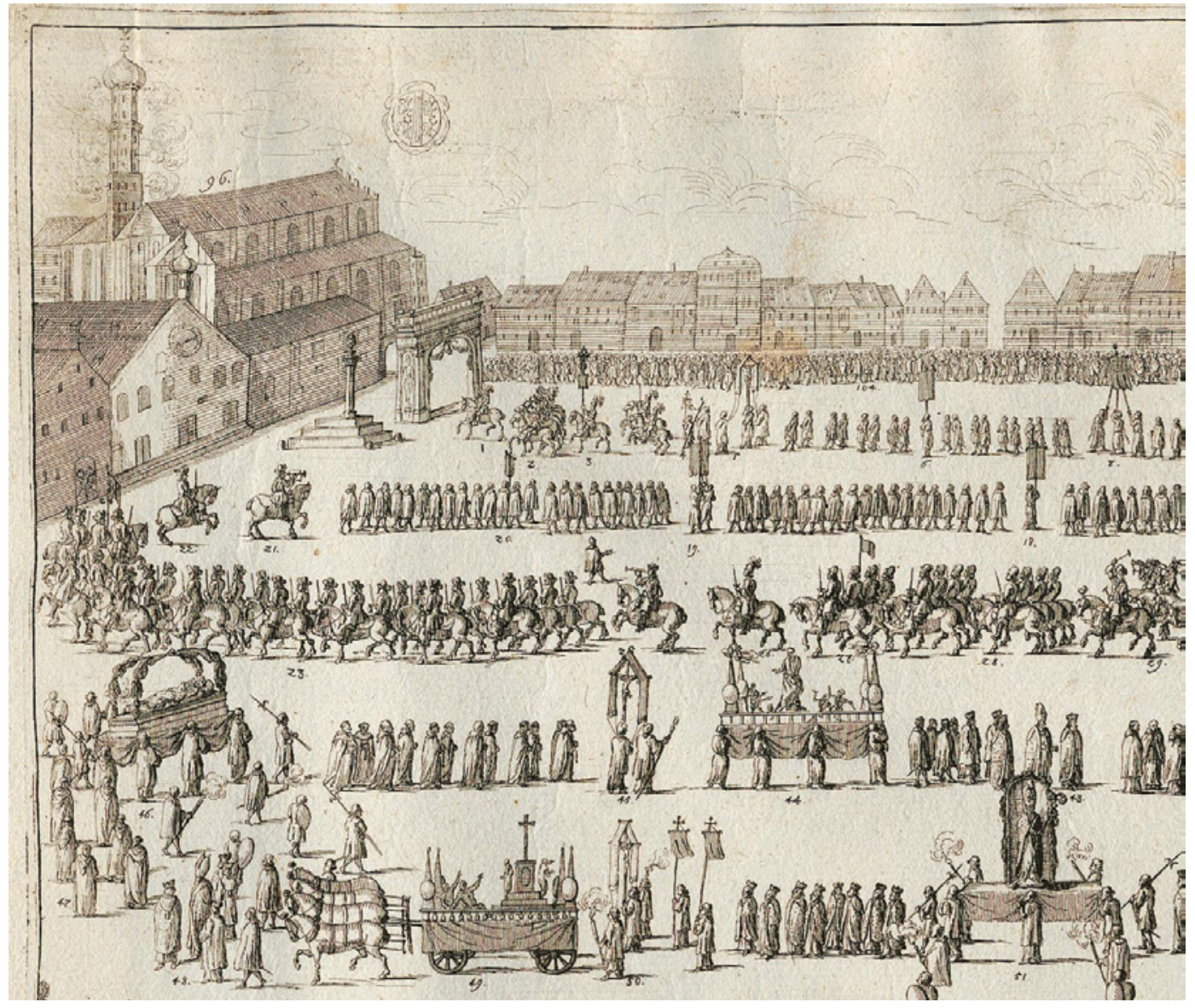

FIGURE 149

Detail of Fig. 148

presenting both a triumph over heathendom as well as a continuity with Christianity's earliest days, two of the contemporary Catholic Church's main goals were realized at once.

Triumphalism was also central to translatio ceremonies in the Low Countries. Of course, even though the territories were far away from the antique capital, they too belonged to the Church of Rome, and the rhetorical language used in Italy thus preserved all its pertinence. The most striking example is perhaps the 1612 ceremony in Lille, which in Buzelin's official report is referred to as a triumphus. Furthermore, in the book's foreword the translation is explicitly presented as a devout, Christian triumph, as opposed to conceited, antique triumphs. Buzelin emphasizes that Saint Victor deserved a splendid triumphal march as much as Alexander the Great did, but the author explains the differences point by point. For instance, instead of being carried around by golden chariots, the saint was carried on the shoulders of priests. Moreover, the parade was not 


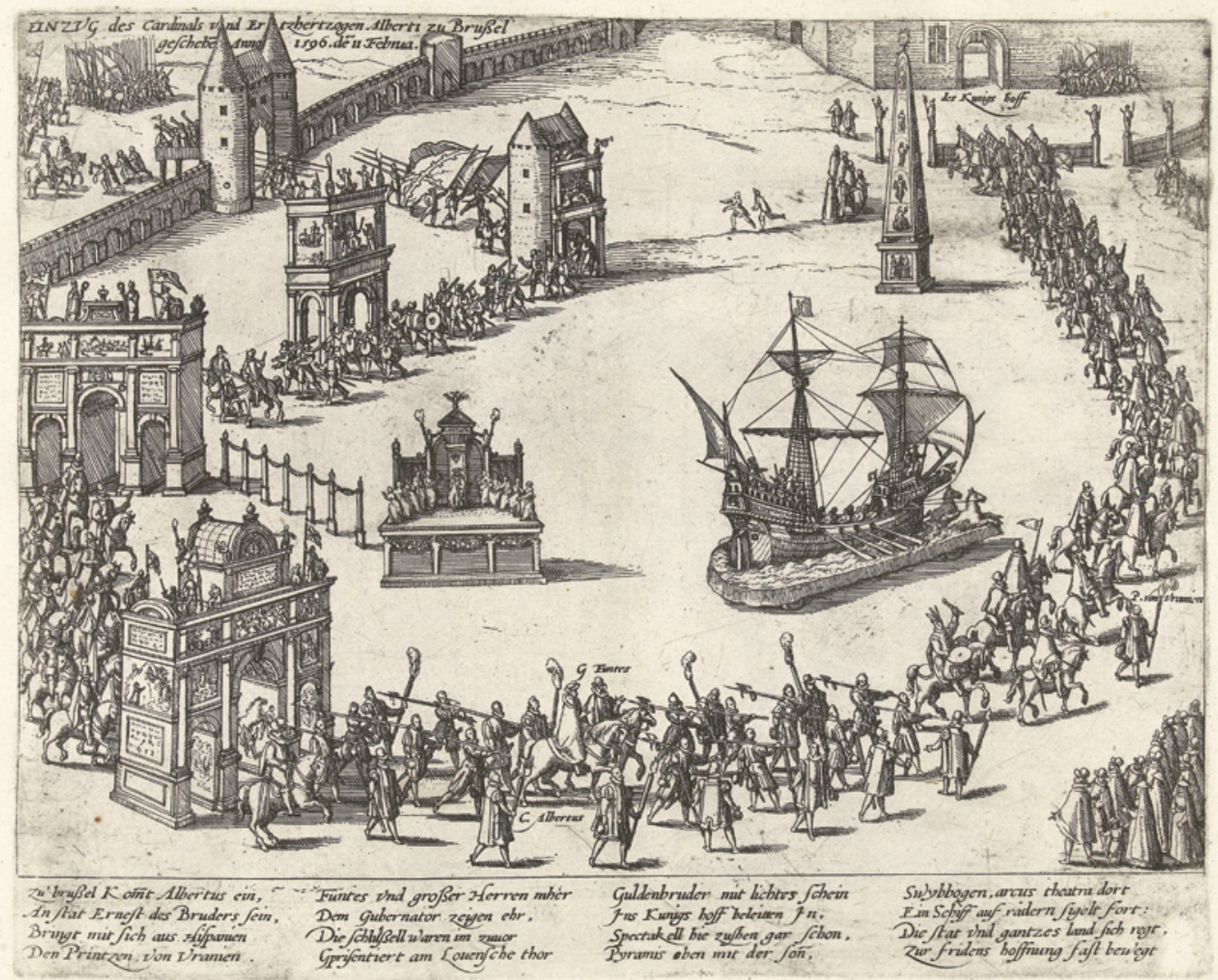

FIGURE 150

Frans Hogenberg, Joyous

Entry of Archduke Albert in Brussels, c. 1596-1598,

Amsterdam, Rijksmuseum preceded by a jester and followed by a retinue of slaves. Rather, it was headed by prominent and devout people, and closed by the Bishop of Tournai. ${ }^{91}$ Finally, even the name of this otherwise completely unknown Saint Victor is particularly suited to the occasion; so much so that one might suspect that it was invented especially for the occasion.

It is noteworthy, however, that in the particular context of the Low Countries, translation ceremonies were related to the traditional Joyous Entries of sovereigns into the cities of their territories. Ephemeral triumphal arches decorated with coats of arms, theatrical representations on stages spread throughout the city and artillery volleys were all essential elements of such public ceremonies as well (fig. 150)..$^{92}$ As a matter of fact, this contemporary association is not limited to formal similarities, but extends to the identical terminology used (innecomen or incomste). In Zoutleeuw, the event is referred to as 'when the holy relic of our patron Saint Leonard was welcomed' or 'brought in'.93 This is illustrative of the translation's 
important association with secular authority. As the archducal government wholeheartedly embraced and actively promoted the Church of Rome, the latter's triumphs in a way were also theirs. This was of course most evident in the various Brussels ceremonies discussed above, but in Zoutleeuw it must have been the case as well, as the relic was donated by an officer of the Spanish army, and therefore a representative of the Habsburg authority. Joyous Entries were furthermore crucial moments of power negotiation: while the cities promised obedience and loyal submission, the sovereign assured protection and respect for the local privileges. Reciprocal gifts were essential items in such ceremonies and have been described as personalized items 'in a bigger process of exchange and as a confirmation of the outcome of political negotiations which could differ with time and place'. ${ }^{94}$ The fact that relics and sovereigns were treated in a similar fashion suggests similar things were expected from them. These observations confirm the interpretation proposed above: just as the donation of the relic had been the result of negotiations, the precise form of its translation was an expression of devotional communication between town and government, whereby one of the main demands was protection. Just as an entering sovereign who would promise his protection to a town, the relic was supposed to serve a requested apotropaic function for the Zoutleeuw community.

Viewing the events at Zoutleeuw in terms of negotiation is in keeping with recent historiographical trends on the course of the Counter-Reformation. Instead of the traditional monolithic, topdown approach, Craig Harline proposed to interpret the process as a cultural negotiation in a local context, and Ditchfield likewise stressed dynamic interaction and processes of reciprocity. ${ }^{95}$ The present case study fully confirms and expands these views. Thus, we can say that even if ecclesiastical control had markedly increased for a century already, the 'culture of the miraculous' preceded ecclesiastical and governmental actions to an important extent. First miracles were reported, and an intervention 'from above' would only follow later on. The Zoutleeuw churchwardens first commissioned the painting depicting Paulus Gautier's miracle, and only later received the relic. The archducal court reacted to local initiatives, rather than creating a revival of Catholicism out of nothing. But although such interventions from above rarely lay at the base of the devotional developments, they nevertheless incorporated and perpetuated them. The case of the relic donation to Zoutleeuw by a courtier fully fits these observations. Through the process of negotiation, the cult received an archducal touch and was invested with new meaning. 